\title{
Analisis Penerapan Just In Time (JIT) dalam Meningkatkan Efesiensi Biaya Produksi
}

\author{
Meika Purnamasari*, Epi Fitriah \\ Prodi Akuntansi, Fakultas Ilmu Ekononi dan Bisnis, Universitas Islam \\ Bandung, Indonesia. \\ *meikapurnamasari2017@gmail.com,epi_fitriah@yahoo.com
}

\begin{abstract}
Just In Time is a system designed to get good quality, get costs, and achieve time and cost as efficiently as possible by eliminating existing waste. This research was carried out in the Forging, Cast and Railroad Division of PT PINDAD (Persero) Bandung, aimed at understanding the timely application of production activities and analyzing the application of just in time to improve production cost efficiency. The method of data collection is done by observing the collected objects. The data analysis technique used is a qualitative descriptive analysis technique. The results of this study indicate that the purchasing system implemented in 2013 is still ineffective, because it still uses a system that uses traditional methods that cause waste of costs and storage space. The company PT PINDAD (Persero) Bandung after implementing a timely production system on one of the products, entered into an agreement with the supplier regarding the quality, quantity, and time of delivery of raw materials by making an agreement with a supplier of the company to minimize production costs. In conducting production activities, the company gets $93.11 \%$ and efficiency levels increase by $5 \%$ so that these activities can be said to be efficient.
\end{abstract}

Keywords: on time, cost efficiency, production

\begin{abstract}
Abstrak. Just In Time adalah suatu sistem yang dirancang untuk mendapatkan kualitas yang baik, menekan biaya, dan mencapai waktu dan biaya seefisien mungkin dengan menghilangkan pemborosan yang ada. Penelitian ini dilakukan di Divisi Tempa, Cor dan Alat Perkeretaapian PT PINDAD (Persero) Bandung, bertujuan untuk mengetahui penerapan Just In Time dalam aktivitas produksi serta menganalisis penerapan Just In Time dalam meningkatkan efisiensi biaya produksi. Metode pengumpulan data dilakukan dengan melakukan observasi pada objek yang diteliti. Teknik analisis data yang digunakan adalah teknik analisis secara deskriptif kualitatif. Hasil penelitian ini menunjukkan bahwa sistem pembelian secara tradisional yang diterapkan pada tahun 2013 masih belum efektif, karena masih menggunakan sistem secara pendekatan tradisonal yang menyebabkan pemborosan biaya dan ruang penyimpanan. Perusahaan PT PINDAD (Persero) Bandung setelah menerapkan sistem produksi secara Just In Time pada salah satu produk, mengadakan kesepakatan dengan pemasok mengenai kualitas, jumlah, dan waktu pengiriman bahan baku dengan adanya kesepakatan dengan pemasok perusahaan dapat meminimalisir biaya produksi. Dalam melakukan aktivitas produksi, perusahaan mendapatkan aktivitas nilai tamba sebesar $93,11 \%$ dan tingkat efisiensi meningkat sebesar 5\% sehingga aktifitas tersebut dapat dikatakan efisien.
\end{abstract}

Kata Kunci: just in time, efisiensi biaya, produksi 


\section{A. Pendahuluan}

Just In Time merupakan suatu kegiatan proses produksi yang dilakukan untuk meminimalisirkan biaya dan ruang penyimpanan. Saat ini dalam melakukan kegiatan produksi, PT PINDAD (Persero) dalam keseluruhan menggunakan dua metode yang pertama metode Make To Stock dimana metode tersebut PT PINDAD (Persero) membuat persediaan produksi barang dalam jumlah kecil dan dilakukan tidak secara rutin dan yang kedua, Make To Order disini PT PINDAD (Persero) masih menggunakan metode Just In Time (JIT) yang dianggap mampu membantu produksi secara tepat waktu dan meminimalisirkan pemborosan terlebih dalam penyimpanan barang dalam gudang. Asep (Kepala Divisi Tempa, Cor dan Perkeretaapian PT PINDAD) menyebutkan permasalahan kendala dalam menggunakan Just In Time dalam melakukan produksi Make To Order adalah dalam harga material yang berubah berubah dikarenakan barang material untuk melakukan produksinya kebanyakan harus di impor dan kurs dollar yang berubah menjadi kendala dikarenakan pada saat melakukan perjanjian awal order dengan konsumen kurs dollar dalam keadaan turun dan saat melakukan produksi kurs dollar melonjak naik sehingga berpengaruh terhadap semua biaya material produksi tersebut. Ketidakstabilan dalam harga material impor barang membawa dampak yang mampu merugikan bagi perusahaan. Karena harga pokok produksi naik dapat merubah harga jual yang naik ataupun tidak sehingga mampu membuat perusahaan tidak mendapatkan laba ataupun mendapatkan laba yang kecil. Sebagai perusahaan manufaktur, yang mengolah bahan baku menjadi produk jadi maka just in time sangat penting diterapkan pada perusahaan. Maka, perusahaan tidak perlu lagi menimbun bahan maupun komponen di pabrik dalam jumlah yang besar, karena produsen dapat memenuhi kebutuhan mereka secara tepat waktu, tepat jumlah dan tepat harga, sehingga dengan efisiennya waktu yang digunakan dalam produksi maka secara langsung perusahaan dapat mengukur kemampuannya dalam hal peningkatan kapasitas produksi berdasarkan waktu.

\section{B. Landasan Teori}

\section{Just In Time}

Menurut (Schroeder, 1994:79) Just In Time pertama kali dikembangkan di negara Jepang yang telah diaplikasikan secara nyata sejak awal tahun 1970-an pada perusahaan manufaktur di Jepang. Pada awalnya di Toyota Motor oleh Mr. Taichii Ono, seorang wakil direktur utama, serta beberapa teman sejawatnya, diantaranya Shigeo. Shigeo mengadopsi strategi Henry Ford yang disesuaikan dengan etos kerja masyarakat Jepang sehingga lahirlah sebuah filosofi yang disebut sebagai Just In Time. Sedangkan menurut Mulyadi (1993:25-26) mengungkapkan Just In Time adalah usaha untuk mengurangi waktu penyimpanan (storage time) yang merupakan suatu akibat dari aktivitas bukan penambah nilai bagi konsumen (nonvalue added activities).

\section{Efisiensi Biaya produksi}

Menurut Vincent Gasperz (2005: 175) Efisiensi adalah ukuran yang menunjukkan bagaimana baiknya sumber-sumber daya ekonomi digunakan dalam proses produksi untuk menghasilkan output. Sedangkan menurut Syahu Sugian (2006:76) Efisiensi biaya produksi adalah hubungan perbandingan antara anggaran biaya produksi (input) dengan realisasi biaya produksi (output). 


\section{Hasil Penelitian dan Pembahasan}

Tabel 1. Proses Produksi Isolating Cock dengan metode Just In Time pada divisi Tempa, Cor, dan Alat Perkeretaapian di PT. PINDAD (Persero) Bandung Tahun 2019

\begin{tabular}{|c|c|c|c|c|c|c|}
\hline \multirow{2}{*}{$\begin{array}{l}\text { Nomor } \\
\text { Operasi }\end{array}$} & \multirow{2}{*}{ Uraian } & \multirow{2}{*}{ Jenis Mesin } & \multicolumn{4}{|c|}{ Waktu } \\
\hline & & & Ts & Tn & Tn & Tn \\
\hline 1 & Menyediakan Komponen pos 1 s/d pos 19 & Manual & 01.00 & 01.00 & 01.10 & 00.50 \\
\hline 2 & Bus (Pos 4.2) diberi Locktite pasang pada Rumah (Pos 4.1) & Ms. Press Tangan & 01.00 & 00.45 & 00.48 & 00.40 \\
\hline 3 & $\begin{array}{l}\text { Pen (Pos 19) diberi Locktite kemudian pasang pada Penutup (Pos } \\
\text { 18) dipres sampai kedap udara }\end{array}$ & Ms. Press Tangan & 01.00 & 00.40 & 00.38 & 00.41 \\
\hline 4 & $\begin{array}{l}\text { Pasang } 0 \text { - Ring (Pos 11) pada Bola segmen (Pos 2), masukan pada } \\
\text { hasil operasi } 20 \text { kemudian ditutup oleh hasil operasi } 30 \text { kencangkan } \\
\text { dengan momen puntir } 250 \mathrm{Nm} \text { sampai kedap udara }\end{array}$ & Ms. Press Tangan & 01.30 & 01.18 & 01.20 & 01.10 \\
\hline 5 & $\begin{array}{l}\text { Masukan Gasket (Pos 8) pada hasil operasi } 40 \text { kemudian pasangkan } \\
\text { Baud Ventilasi (Pos 9) dengan moment puntir } 100 \mathrm{Nm}\end{array}$ & Manual & 01.00 & 01.00 & 00.59 & 00.57 \\
\hline 6 & $\begin{array}{l}\text { Masukan Gasket (Pos 3) pada hasil operasi 50, Pasang Flens (Pos 1) } \\
\text { di ikat dengan Baud (Pos 5), Mur (Pos 6) dan Ring (Pos 7) }\end{array}$ & Manual & 01.30 & 01.21 & 01.18 & 01.05 \\
\hline 7 & $\begin{array}{l}\text { Masukan Pegas (Pos 15) dan Pegas (Pos 14) pada Pasak (Pos 16) } \\
\text { kemudian ditutup dengan Cincin (Pos 17). Selanjutnya dimasukan } \\
\text { ke Handel (Pos 10) di ikat dengan Pen. }\end{array}$ & Manual & 01.30 & 01.45 & 01.25 & 01.10 \\
\hline 8 & $\begin{array}{l}\text { Pengetesan: } \\
\text { Uji kebocoran diberi tekanan } 10 \text { bar (udara) }\end{array}$ & Ms. Test & 06.00 & 06.00 & 06.00 & 06.00 \\
\hline 9 & $\begin{array}{l}\text { Pasangkan Pen (Pos 13) pada hasil operasi } 60 \text { kemudian pasang } \\
\text { hasil operasi } 70 \text { di ikat dengan Pen (Pos 12) }\end{array}$ & Manual & 02.00 & 02.00 & 02.00 & 02.00 \\
\hline 10 & Pasang tutup pelindung pos 20 dan pos 21 & Manual & 00.30 & 00.25 & 00.27 & 00.26 \\
\hline \multirow[t]{4}{*}{11} & Diperiksa & Manual & 01.00 & 01.00 & 01.00 & 01.00 \\
\hline & & Total & \multirow{3}{*}{18.00} & 17.23 & 17.08 & 15.98 \\
\hline & & Total Tn & & & & 50.29 \\
\hline & & Rata-Rata & & & & 16.76 \\
\hline
\end{tabular}

Sumber: data perusahaan yang diteliti

Perusahaan mengestimasikan waktu yang di sebut Ts (Time Standar) selama 18 menit sedangkan saat dilakukan observasi untuk pembuatan 1 buah Isolating Cock hanya memerlukan waktu nyata (Tn) selama 16.76menit. Berarti terjadi efisiensi dari sisi ini sebesar 1.24 menit. Penurunan yang terjadi atas waktu tersebut mampu membuat peningkatan terhadap kecepatan kinerja karyawan dalam memproduksi dengan meningkatkan jumlah produksi yang lebih banyak sebesar 8,24. Sehingga hasil produksi meningkat sebesar $7 \%$.

Berdasarkan hasi penelitian, maka penerapan metode Just In Time di Divisi Tempa, Cor dan Alat Perkeretaapian pada PT PINDAD (Persero) Bandung termasuk dalam kategori efisien. Ini dapat dilihat dari hasil yang diperoleh dengan menggunakan rumus MCE (Manufacturing Cycle Eficiency) yang dikemukakan oleh Supriyono (1999: 8) dalam pengukuran metode Just In Time sebagai berikut:

\begin{tabular}{|c|}
\hline Waktu Pengolahan \\
\hline Masa Pabriksasi \\
\hline
\end{tabular}

Hasil yang di peroleh dari perhitungan dari data perusahaan ada sebesar 93,11\% hasil dari aktivitas produksi yang artinya hasil tersebut adalah biaya nilai tambah, walaupun demikian masih biaya aktivitas tidak nilai tambah yang didapat yaitu sebesar 6,89\%. Hal ini disebabkan, masih adanya waktu tunggu dalam aktivitas produksi di perusahaan. Berikut perhitungan aktivitas produksi dengan rumus MCE :

$$
16,76 \text { menit } \quad x 100 \%=93,11 \%
$$

PT PINDAD (Persero) Bandung merupakan perusahan yang bergerak di bidang manufaktur. Tujuan utamanya adalah berujuan untuk memperoleh laba, PT PINDAD Bandung juga harus bersaing dengan pasar produk manufaktur dan sejenisnya. Perusahaan terus berusaha 
untuk mendapatkan kepuasan dan kepercayaan dari pelanggan terutama dalam ketepatan waktu, biaya serta kualitas produk. Biaya produksi dalam membuat 1 buah isolating Cock meliputi biaya yang diperlukan sebagai berikut:

1. Biaya bahan baku

Persediaan bahan baku yang diterapkan oleh perusahaan selama ini dengan melakukan pembelian berdasarkan total kebutuhan bahan baku dan kebutuhan persediaan minimal persediaan ketika mendapatkan pesanan.

2. Biaya tenaga kerja langsung

Biaya tenaga kerja langsung yang ditetapkan perusahaan adalah Rp. 25.000/jam kerja. Dimana tenaga kerja langsung untuk memproduksi Isolating Cock sebanyak jam kerja per hari adalah 7 jam.

3. Biaya overhead pabrik meliputi biaya pemakaian mesin

Biaya overhead pabrik perusahaan adalah biaya pemakaian mesin langsung. Biaya pemakaian mesin langsung yang ditetapkan perusahaan adalah Rp. 30.000/jam kerja.

Tabel 2. Anggaran biaya dan realisasi biaya untuk produksi Isolating Cock tahun 2019

\begin{tabular}{|c|c|c|c|}
\hline Keterangan & Anggaran Biaya & Realisasi Biaya & Selisih \\
\hline \multicolumn{4}{|l|}{ Bahan Baku Langsung } \\
\hline Bola Segmen & 210.000 & 210.000 & 0 \\
\hline Rumah Isolating Cock & 90.000 & 90.000 & 0 \\
\hline Handle & 50.000 & 50.000 & 0 \\
\hline Baud Ventilasi & 60.000 & 60.000 & 0 \\
\hline Pasak & 160.000 & 160.000 & 0 \\
\hline Penutup & 300.000 & 300.000 & 0 \\
\hline Flens & 150.000 & 150.000 & 0 \\
\hline Tutup Pelindung (Ulir Luar) & 10.000 & 0 & 10.000 \\
\hline Dowel Pin Misumi Ms & 10.000 & 10.000 & 0 \\
\hline Cincin & 5.000 & 1000 & 4.000 \\
\hline Pegas 2441 & 10.000 & 10.000 & 0 \\
\hline Pegas 2442 & 5.000 & 5.000 & 0 \\
\hline Dowel Pin Misumi Mstm & 20.000 & 20.000 & 0 \\
\hline Roll Pen Din & 5.000 & 5.000 & 0 \\
\hline 0-Ring & 5.000 & 5.000 & 0 \\
\hline Sealing Ring & 15.000 & 15.000 & 0 \\
\hline Mur Din & 10.000 & 10.000 & 0 \\
\hline Bolt Din & 10.000 & 10.000 & 0 \\
\hline Cincin A10.5 & 5.000 & 5.000 & 0 \\
\hline Gasket & 15.000 & 15.000 & 0 \\
\hline Tutup Pelindung (Ulir Dalam) & 5.000 & 5.000 & 0 \\
\hline & 1.150 .000 & 1.136 .000 & 14.000 \\
\hline \multicolumn{4}{|l|}{ Biaya Tenaga Kerja Langsung } \\
\hline 4MAN/ Labor Rate & 5.000 & 5.000 & 0 \\
\hline 4KIT2/ Labor Rate & 20.000 & 20.000 & 0 \\
\hline \multicolumn{4}{|l|}{ Biaya Overhead Pabrik } \\
\hline 4MAN/ Overhead Rate & 15.000 & 15.000 & 0 \\
\hline 4KIT2/ Overhead Rate & 40.000 & 40.000 & 0 \\
\hline Total Biaya keseluruhan & 1.205 .000 & 1.191 .000 & 14.000 \\
\hline
\end{tabular}

Dari tabel 2. maka dapat diketahui harga bahan baku standar dan bahan baku nyata untuk pembuatan produksi isolating cock dimana biaya tersebut merupakan biaya satuan. Untuk bahan baku yang tertera diatas ada 21 harga beberapa komponen, biaya tenaga kerja langsung (Labor Rate) dan biaya overhead (Overhead Rate) maka total biaya keselurugan ada 23 detail biaya tersebut. 1 buah isolating cock perusahaan mengestimasikan biaya sebesar 1.205 .000 namun 
yang terjadi lebih menurun hanya 1.191 .000 selisih sebesar 14.000 dari biaya yang telah diestimasikan. Menurut bapak andri selaku Keuangan di bagian divisi Tenpa, Cor dan Perkeretaapian menyebutkan biaya diatas adalah biaya yang ditanggung oleh perusahan akibat adanya pemesanan produksi yang secara tiba-tiba mematok waktu yang sangat singkat sehingga untuk mencarikan bahan baku nya terkadang susah harga kadang lebih mahal.

Tabel 3. Perbandingan Harga per unit Isolating Cock tahun 2019

\begin{tabular}{|l|c|c|}
\hline Isolating Cock & Metode Tradisional & Metode JIT \\
\hline Waktu nyata & 25 & 16,76 \\
\hline Waktu Produksi Sehari & 420 & 420 \\
\hline Produksi Sehari (unit) & 16,8 & 20,05 \\
\hline HPP per Unit & 1.251 .000 & 1.191 .000 \\
\hline Total biaya produksi sehari & 21.016 .800 & 23.879 .550 \\
\hline Harga jual per unit & 1.501 .000 & 1.429 .000 \\
\hline Total harga jual & 25.216 .800 & 28.651 .450 \\
\hline
\end{tabular}

Sumber : Data diolah

Perbandingan harga untuk 1 buah Isolating Cock yang ada di tabel 4.10 dapat dilihat dengan HPP per unit metode pendekatan tradisional Rp. 1.251.000 dan Harga jual per unit sebesar Rp.1.501.000. sedangkan untuk metode Just In Time HPP per unit Rp. 1.191.000 dan harga jual sebesar Rp. 1.429.000 yang membedakan dari kedua metode ini ialah pengeluaran biaya metode tradisional yang lebih besar karena didalamnya mencakup biaya tenaga kerja langsung dan overhead pabrik yang lebih besar. Namun, saat frekuensi produksi yang dilakukan dengan metode Just In Time ternyata lebih besar 9buah dari metode tradisional sehingga saat hasil total biaya produksi yang dilakukan sehari dengan HPP mendapatkan selisih yang merupakan laba perusahaan sebesar Rp 4.771.900 dimana laba itu lebih besar didapatkan sebesar 16-17\% dalam produksi seharinya. Laba perhitungan presentase didapat dari perolehan perhitungan produksi metode JIT dikurang dengan produksi metode pendekatan tradisional lalu dibagi dengan produksi sehari metode just in time dan dikalikan $100 \%$. Laba yang di peroleh produksi isolating cock cukuplah besar dibanding metode tradisional sehingga perusahaan mendapat keuntungan yang besar. Tabel tersebut juga terlihat bahwa terjadi penurunan biaya HPP yang didalamnya terdapat biaya tenaga kerja dan biava pemakaian mesin sebesar 5\%. Hal ini dikarenakan, dengan menggunakan metode JIT perusahaan menggunakan dasar waktu produksi sesungguhnya untuk menghitung biaya tenaga kerja dan biaya pemakaian mesin Sedangkan metode yang digunakan perusahaan sebelum menggunakan JIT, perusahaan menggunakan dasar waktu jam kerja biasa pada setiap harinya tanpa menghitung hasil produksi yang telah dilakukan. Dengan menggunakan waktu produksi sesungguhnya, maka perusahaan dapat mengendalikan dan mengontrol proses produksi dengan baik sesuai dengan waktu yang telah ditentukan dalam setiap tugas kerja sehingga dapat meningkatkan kualitas dan mutu produk.

Penelitian ini didukung oleh Penelitian yang dilakukan Nurhidayati (2017) dan Sultan Sarda (2019) yang menyatakan bahwa penerapan metode Just In Time dapat meningkatkan efisiensi biaya produksi perusahaan.

\section{Kesimpulan}

Berdasarkan hasil penelitian dan pembahasan, maka kesimpulan dari penelitian ini adalah:

1. Metode just in time yang diterapkan oleh perusahaan untuk mengurangi masalah keterlambatan waktu, mengeluarkan biaya tambahan dan penumpukan di gudang sebelumnya sehingga untuk mengurangi masalah-masalah yang ada

2. Tingkat efisiensi biaya produksi Isolating Cock yang terjadi pada PT PINDAD (Persero) Bandung sebesar 5\%. Hal ini dilihat dari perbandingan biaya produksi untuk satu buahnya sebesar 60.000 lebih kecil dibandingkan dengan biaya produksi sebelumnya. Terjadi dikarenakan ada pengurangan biaya-biaya dalam melakukan kegiatan produksi 
Isolating Cock seperti biaya tenaga kerja langsung dan biaya overhead pabrik.

3. Penerapan metode Just In Time pada perusahaan dapat meningkatkan efisiensi biaya produksi. Pembelian dapat dilakukan dalam jumlah yang kecil dan pengiriman secara berkala, sehingga dapat menekan terjadinya biaya penyimpanan pada perusahaan. Serta dengan metode ini, dapat menurunkan aktivitas biaya tidak bernilai tambah. Dengan menggunakan metode Just In Time perusahaan lebih efisien 93,11\% dalam setiap melakukan produksi dan meningkatkan aktivitas biaya produksi sebesar 5\% dibandingkan dengan metode yang sebelumnya.

\section{E. Saran}

Adapun saran-saran untuk perubahan yang perlu dilakukan oleh perusahaan yaitun:

1. Perusahaan sebaiknya menerapkan sistem Just In Time pada keseluruhan proses produksinya. Karena dengan menerapkan sistem Just In Time perusahaan dapat mengurangi biaya yang tidak bernilai tambah akibat kelebihan biaya penyimpanan bahan baku, dan dapat membeli bahan baku dalam jumlah, mutu, dan waktu yang tepat.

2. Aktivitas tingkat efisiensi biaya produksi yang ada dalam produksi Isolating Cock sebaiknya lebih ditekankan lagi dalam biaya yang dikeluarkan dalam setiap unit nya. Supaya mampu meningkatkan lagi efisiensi biaya produksi dan melakukan produksi lebih banyak dengan waktu cepat.

3. Pelaksanaan kegiatan produksi sebaiknya keseluruhan menggunakan metode Just in Time agar kualitas produk tetap terjaga dan dipercayai oleh konsumen sehingga mampu meningkatkan efisiensi biaya perusahaan untuk mendapatkan laba yang diinginkan.

\section{Daftar Pustaka}

[1] Gasperz,Vincent. 2005. Ekonomi Manajerial: Pembuatan Keputusan Bisnis. Jakarta: Penerbit PT. Gramedia Utama.

[2] Mulyadi. 1993. Sistem Akuntansi. Edisi ke-3. Bagian Penerbitan Sekolah Tinggi Ilmu Ekonomi YKPN.

[3] R.A. Supriyono. 1999. Akuntansi Biaya Buku I Edisi 2: Pengumpulan Biaya dan Penentuan Harga Pokok. Yogyakarta: BPFE

[4] Schroeder, Roger G. 1994. Manajemen Operasi : Pengambilan Keputusan dalam Suatu Fungsi Operasi, Jilid 2, Edisi Ketiga. Jakarta: Erlangga

[5] Sugian, Syahu. 2006. Kamus Manajemen Mutu. Jakarta: Gramedia Pustaka Utama 